\title{
BIOACTIVITY OF NEOLIGNANS FROM FRUCTUS SCHIZANDRAE
}

\author{
LI Xiao-Yu \\ Shanghai Institute of Materia Medica, Chinese Academy of Sciences, 319 Yue-Yang Rd., Shanghai 200031, \\ China
}

Fructus Schisandrae sinensis Baill, a traditional Chinese medicine, used as tonic and sedative, has been shown at the beginning of 70's to lower the elevated serum glutamic-pyruvic transaminase (SGPT) levels of patients suffering from chronic viral hepatitis. During past 20 years, a series of neolignans have been isolated and identified as effective principles. Pharmacological studies revealed that they increased liver protein and glycogen synthesis, antagonized liver injuries from $\mathrm{CCl}_{4}$ and thioacetamide. The mechanism of SGPT lowering was considered as a hepato-protective and membrane stabilize action, although inhibition of the activity of liver GPT may also be existed. It was found that some principles of Schisandrae have an inducing effect on hepatic microsomal drug-metabolizing enzyme system P-450, thus explained their anti-toxic, anti-carcinogenic and anti-mutagenic effects. A synthetic derivative compound of Schisandrin called DDB has most of the above mentioned actions now used widely in China as a hepato-protective drug with high effectiveness in normalizing liver functions and very low side effects. From natural Schisandrin to synthesized $D D B$, pointed out a successful way in the development of new drugs from natural products.

Key words: Fructus Schizandrae - Schizandraceae - dibenzocyclooctene neolignans hepatoprotective agents - DDB

The fruits of Schizandrae sinensis Baill., Schisandrae sphenanthera Rehd et Wils. and other species belonging to the Schizandraceae family were used in traditional Chinese medicine as tonic and sedative for about two thousands years. At the beginning of 70's, clinical investigations reported that Fructus Schizandrae are effective for treatment of viral and chemical hepatitis, especially in lowering the elevated serum glutamic-pyruvate transaminase (SGPT) levels. During past 20 years, near 40 compounds were isolated from this kind of herbs, they were identified as derivatives of dibenzo[a,c] cyclooctene, and some of the neolignans were active hepatoprotective principles. Here is a brief review of the pharmacological studies made by Chinese scientists, including their effects on liver injuries and the mechanism of SGPT lowering, effects on hepatic microsomal cytochrome P-450 induction and on antioxidation. The investigations lead to discovery of a synthetic derivative of schizandrin called DDB (dimethyl-4,4'-dimethoxy-5,6,5',6',-dimethylenedioxy-biphenyl-2,2'-dicarboxylate) now used widely in China for the treatment of hepatitis.

The chemical structures and nomenclatures are shown in Fig. 1.

\section{EFFECTS ON LIVER INJURIES INDUCED BY CHEMICAL TOXICANTS}

Several neolignans isolated from the dried fruit of Schizandraes were shown to be active in lowering the high SGPT level to various extents in $\mathrm{CCl}_{4}$ and thioacetamide intoxicated mice or rats (Bao, et al., 1979), see Table I.

Table I showed that Sin C, Sol B and Ser B were more potent than other principles. From another report (Shanghai Institue of Materia Medica, 1976), Ser A, the highest yield lignan in Schisandrae sphenanthera was also very effective in lowering SGPT. Histological studies revealed that in $\mathrm{CCl}_{4}$ intoxicated liver, widely necrosis and acid degeneration of liver cells were seen in the central regions of lobules, which were substituted by neutrophilcyte infiltrations. The liver of treated animals were much better. Ultrastructural modifications of hepatic cells of Ser A on acute and chronic $\mathrm{CCl}_{4}$ intoxication were shown as Fig. 2. The hepatic cellular injuries were protected and this component has no direct toxic action on liver cells. 
<smiles>COc1cc2c(c(OC)c1OC)-c1cc(OC)c(OC)c(OC)c1-c1c(cc3c(c1OC)OCO3)CC(C)C(C)C2</smiles>

$\operatorname{Sin} \mathrm{A}$<smiles>COc1cc2c(c(OC)c1OC)-c1c(cc3c(c1OC)OCO3)CCC(C)C2</smiles>

Sol B
$\operatorname{Sin} B$<smiles>COc1c2c(cc3c1-c1c(cc4c(c1OC)OCO4)CC(C)C(C)C3)OCO2</smiles>

$\sin C$<smiles>COc1cc2c(c(OC)c1OC)-c1c(cc(OC)c(OC)c1OC)CC(C)(O)C(C)C2</smiles>

Sol A

Fig. 1 : the molecular structure of the compounds isolated from Fructus Schizandrae chinensis as well as DDB.

TABLE I

Effect of Schizandrae lignans on $\mathrm{CCl}_{4}$ and thioacetamide (TAA) intoxications of mice SGPT

\begin{tabular}{lccc}
\hline & $\begin{array}{c}\text { Dose } \\
\mathrm{mg} / \mathrm{kg}\end{array}$ & Toxicants & $\begin{array}{c}\text { SGPT } \\
\mathrm{u} / 100 \mathrm{ml}\end{array}$ \\
\hline Control & - & & $744 \pm 100$ \\
Sin A & 100 & & $797 \pm 120$ \\
Sin B & 100 & $\mathrm{CCl}_{4}$ & $401 \pm 69^{a}$ \\
Sin C & 100 & $0.01 \mathrm{ml} / \mathrm{kg}$ & $270 \pm 61^{b}$ \\
Sol A & 100 & ip & $776 \pm 127$ \\
Sol B & 100 & & $200 \pm 22^{b}$ \\
Ser B & 100 & & $196 \pm 63^{b}$ \\
\hline Control & - & & $1112 \pm 56$ \\
Sin B & 50 & TAA & $1137 \pm 36$ \\
Sin C & 50 & $100 \mathrm{mg} / \mathrm{kg}$ & $843 \pm 53^{a}$ \\
Sol B & 50 & ip & $637 \pm 90^{b}$ \\
Ser B & 50 & & $438 \pm 40^{b}$ \\
\hline
\end{tabular}

$a: \mathrm{p}<0.05 ; b: \mathrm{p}<0.01$ vs Control.

STUDIES ON THE MECHANISM OF SGPT LOWERING

Effects on tissue enzyme activities - Shanghai Institute of Materia Medica (1976) reported that all the components (e.g. Ser A, Ser B, Sol B) which lowering SGPT could also very significantly lower the activity of liver GPT (LGPT) (Table II). Mice po Ser A $200 \mathrm{mg} / \mathrm{kg}$ for 15 days, GPT, GOT and LDH activitities of liver, heart and kidney were assayed. The results (Table III) showed that the lowering of LGPT was very strong and more potent than that of heart and kidney GPT. The effects on GOT activities in these tissues were less potent and almost no effect of Ser A on tissues LDH activities were detected. It is concluded that the LGPT lowering effect of Ser A is very selective.

Effects on LGPT protein content - In order to test if Ser A is a LGPT enzyme inhibitor, GPT protein was purified from, rat livers. The purified enzyme was identified by SDS-PAGE electrophoresis as a single bond. The enzyme was used together with Freund complete adjavant as antigen for the immunization to rabbits, then anti-GPT serum was obtained. By means of rocket-electrophoresis of antigenantibody precipitations, it was found that GPT protein content of Ser A treated animals were not decreased, but the difference of LGPT activities between control $(302 \pm 170 \mathrm{u})$ and medicated $(93 \pm 49 \mathrm{u})$ groups were very significant, thus concluded that Ser A inhibited the activity of liver GPT (Shanghai Inst. Materia Medica, 1976). 


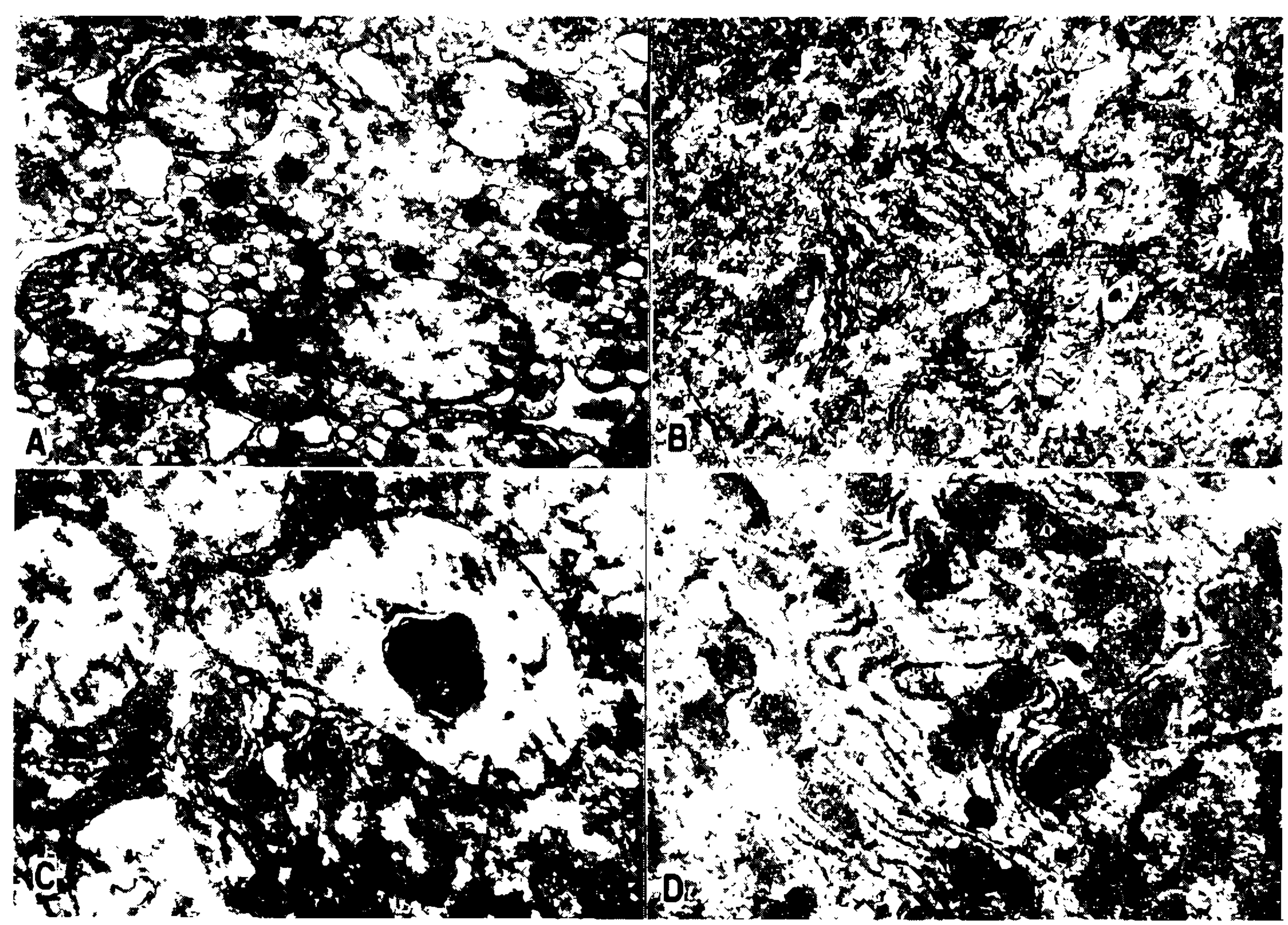

Fig. 2: $\mathrm{A}-\mathrm{CCl}_{4}$ intoxication $19 \mathrm{~h}$ after $\times 16000$ - Showing mitochondria swelling, rupture and lysis of inner cristac, dilation and increases of smooth endoplasmic reticulum and formed vesicles. Several small round microbodies and deep electrodensity particles were seen in the plasma. Ribosome granular of rough endoplasmic reticular were decreased. B - $\mathrm{CCl}_{4}$ acute intoxication with Schizandrer A (Ser A) therapy x 24000 - Showing normal mitochondria. RER and SER were not increased. $\mathrm{C} \ldots \mathrm{CCl}_{4}$ chronic intoxication x 75000 - Mitochondria swelling, cristae rupture and lysis, one of which showing myelinic degeneration. D .. $\mathrm{CCl}_{4} \mathrm{chronic}$ intoxication with Ser A therapy x 24000 .- Normal mitochondria RER, SFR and nuclear.

\section{TABLE II}

Effect of Schizandrac lignans on serum and liver GPT activities in $\mathrm{CCl}_{4}$ intoxicated mice

(unit/ $100 \mathrm{ml}$ or $\mathrm{mg}$ )

\begin{tabular}{lccl}
\hline & $\begin{array}{c}\text { Dosc } \\
\text { mg } / \mathrm{kg}\end{array}$ & SGPT & LGPT \\
\hline Control & - & $343 \pm 31$ & $205 \pm 5$ \\
Sin B & 200 & $202 \pm 17^{a}$ & $194 \pm 6$ \\
Sin B & 400 & $177 \pm 11^{a}$ & $173 \pm 6^{a}$ \\
Sin C & 200 & $201 \pm 13^{a}$ & $179 \pm 6^{a}$ \\
Sin C & 400 & $196 \pm 26^{a}$ & $165 \pm 3^{a}$ \\
Sol B & 100 & $208 \pm 26^{a}$ & $157 \pm 7^{a}$ \\
Ser B & 100 & $228 \pm 21^{a}$ & $115 \pm 6^{a}$ \\
\hline
\end{tabular}

$a: \mathrm{p}<0.01$ vs Control.

Effect on LGPT protein synthesis. By using of ip ${ }^{14} \mathrm{C}$-leucine into rats, the radioactivity incorporated into LGPT was $370 \pm 80$ $\mathrm{cpm} / \mathrm{mg}$ protein in control group and $490 \pm 160$ $\mathrm{cpm} / \mathrm{mg}$ protein in treated group. It is therefore indicated that the synthesis of (iPT was not inhibited. The GPT lowering mechanism of Ser A seems to be related to the inhibition of the activity of LGPT, so that after stopping medication, the activity of SGPT soon arised.

\section{TABLE III}

Effect of Ser A $200 \mathrm{mg} / \mathrm{kg} \mathrm{x} 15 \mathrm{~d}$ on tissue enzy me activity ( $\mu \mathrm{g}$ pyruvic acid/mg tissue)

\begin{tabular}{llrr}
\hline & & Normal & Ser A \\
\hline \multirow{3}{*}{ GPT } & Liver & 188 & 53 \\
& Heart & 11 & 8 \\
& Kidncy & 10 & 8 \\
& & & 33 \\
GOT & Liver & 43 & 47 \\
& Heart & 59 & 36 \\
& Kidney & 37 & 1.5 \\
LDH & Liver & 1.6 & 1.5 \\
& Heart & 1.4 & 1.6 \\
\hline
\end{tabular}


EFFECTS ON LIVER GLYCOGEN CONTENT OF MICE

Glycogenesis was found to be promoted in fasted mice by the administration of Sin A, B, C and Sol B. Among which Sol B was the most effective one with a potency comparable to that of cortisone. Since such an effect can also be shown in adrenalectomized mice, it is resonable to presume that the effect of these agents on glycogenesis is not mediated by the pituitary-adrenal system. No effect on glycogenesis was demonstrated for Ser A, B and Sol A (Table IV).

\section{EFFECT ON PROTEIN AND NUCLEAR ACID} SYNTHESIS IN MICE

Liu et al. (1980) reported that Sin B was found to have protective action on liver injury and to increase the weight of liver in mice. In partially hepatectomized mice, Sin B was shown to increase the protein, RNA and DNA contents as well as mitosis of liver cells. In addition, Sin B was found to enhance the incorporation of ${ }^{14} \mathrm{C}$-phenylalanine into liver protein and to increase hepatic microsomal cytochrome P-450 and protein content significantly (Table V). It is concluded that Sin B is an inducing agent of drug metabolizing enzyme but different from phenobarbital while the later is not able to antagonize $\mathrm{CCl}_{4}$ intoxication in mice.

\section{INTERACTION WITH LIVER CYTOCHROME P-450}

Seven compounds isolated from Schizandrae Fructus and DDB were incubated in vitro with NADPH-reduced microsomes, Sin B, Sin C, Sol B, Ser A and Ser B generated dual Soret peaks at $455-460 \mathrm{~nm}$ and $425-430 \mathrm{~nm}$ (Fig. 3). All these compounds more or less inhibit liver microsomal hydroxylation of benzopyrene (BP) demethylation of aminopyrine. Sin B, Sol B and DDB decreased mutagenicity of BP in Ames test. It is quite possible that these compounds are able to protect against mutagenicity of some mutagens mediated by liver microsomal activation (Liu \& Lesca, 1982a).

\section{ANTI-OXIDANT ACTIVITY}

Liu \& Lesca (1982b) reported the antioxidant properties of dibenzo[a,c]cyclooctene derivatives isolated from Fructus Schizandrae as well as DDB. It is shown that the mechanism of protection against $\mathrm{CCl}_{4}$-hepatotoxicity of these compounds is to inhibit $\mathrm{CCl}_{4}$-induced lipid peroxidation and $\left[{ }^{14} \mathrm{C}_{\mathrm{Cl}}{ }_{4}\right.$ covalent binding to lipids of liver microsomes from phenobarbital-treated mice. The compounds also decreased carbon monoxide (CO) pro. duction and cofactor (NADPH, oxygen) utilization during $\mathrm{CCl}_{4}$ metabolization by liver microsomes (Table VI). It may be postulated that the hepatoprotective effect of these compounds is due to their inhibitory effect

TABLE IV

Effect of p.o. Schizandra lignans on liver glycogen

\begin{tabular}{lcccccccr}
\hline & & \multicolumn{3}{c}{ Liver glycogen (\% of control) } & \multicolumn{2}{c}{ Sl Ser B } & Cortisone \\
\hline Normal mice & Sin A & $\operatorname{Sin}$ B & $\operatorname{Sin}$ C & Sol A & Sol B & Ser A & Ser \\
Adrenalectomized & 159 & 150 & 89 & 149 & 192 & 97 & 98 & 225 \\
\hline
\end{tabular}

TABLE V

Effect of $\mathrm{Sin} \mathrm{B}$ on liver protein, RNA and microsomal $\mathrm{P}-450$ content in $\mathrm{CCl}_{4}$ intoxicated mice

\begin{tabular}{lccc}
\hline & Normal & $\mathrm{CCl}_{4}$ & $\operatorname{Sin~B}+\mathrm{CCl}_{4}$ \\
\hline Protein mg/g & $10.1 \pm 0.1$ & $10.3 \pm 0.4$ & $12.7 \pm 0.6^{\natural}$ \\
RNA mg/g & $0.81 \pm 0.06$ & $0.88 \pm 0.07$ & $0.88 \pm 0.04$ \\
P-450 nM/mg pr. & $0.173 \pm 0.012$ & $0.116 \pm 0.015^{a}$ & $0.268 \pm 0.008^{b}$ \\
\hline
\end{tabular}

$a: p<0.05 ; b: p<0.01$ vs normal mice. 


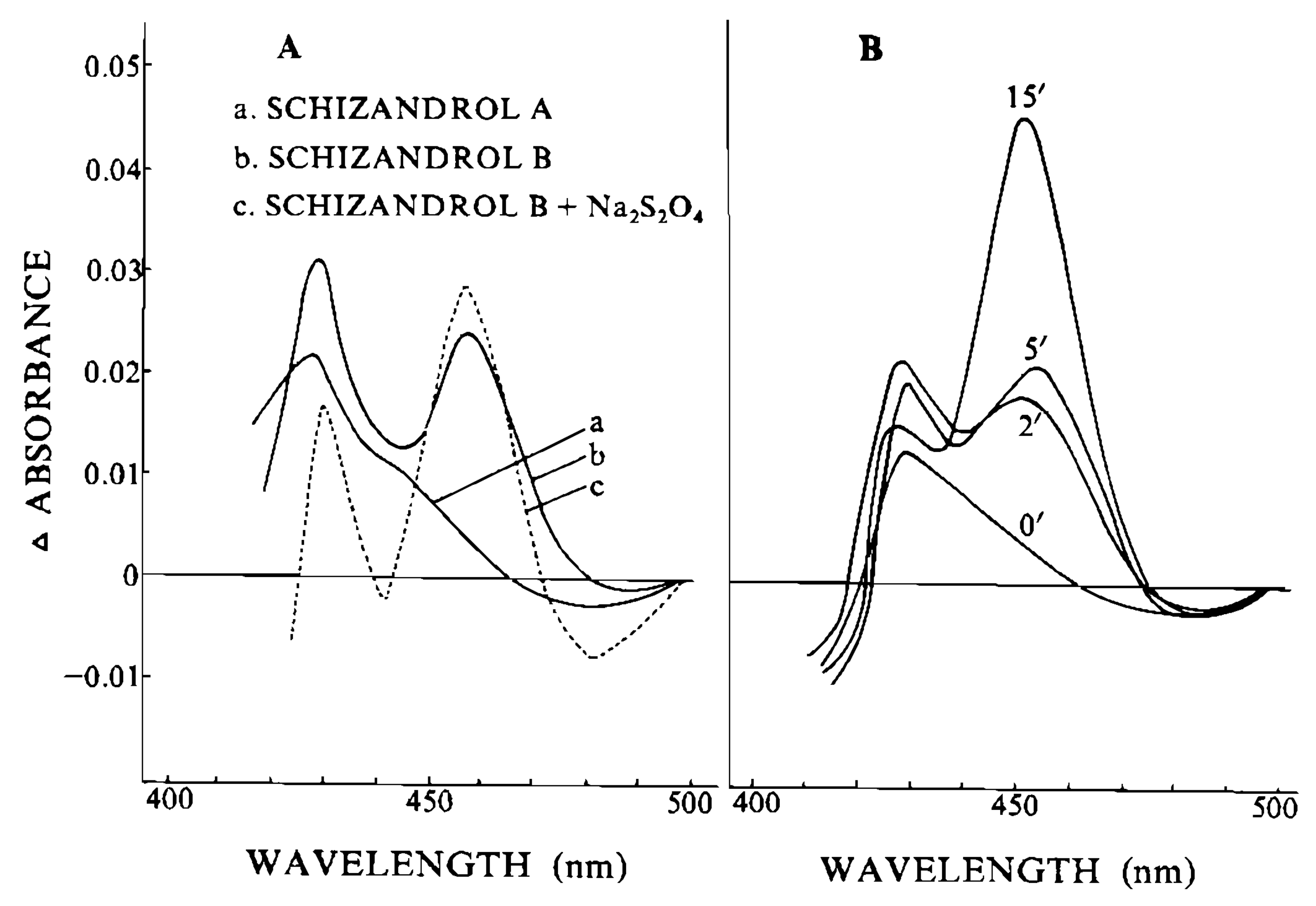

Fig. 3: optical difference spectra formed on incubation of Sol A and Sol B with NADPH-reduced liver microsomes from PB-treated rats. PB-induced liver microsomal suspensions containing $1 \mathrm{mg} / \mathrm{ml}$ and cytochrome $\mathrm{P}-4501.7 \mathrm{nmol} / \mathrm{mg}$ protein; A : solid lines were obtained after addition of Sol A and Sin B to the sample cuvette, respectively; the dotted line was initiated by the addition of $\mathrm{Na}_{2} \mathrm{~S}_{2} \mathrm{O}_{4}$ to both cuvettes after 15-min incubation. $B$ : the timecourse of spectral changes after $0,2-, 5-$ and $15-\mathrm{min}$ incubation of $\mathrm{Sol} B$ under the same conditions as that in Fig. 3A.

\section{TABLE VI}

Summary of the inhibitory effects of schizandrins and DDB on $\mathrm{CCl}_{4}$-induced MDA formation, lipid binding of $\left[{ }^{14} \mathrm{C}\right] \mathrm{Cl}_{4}, \mathrm{CO}$ production, NADPH and ox ygen consumption $(+)$ and $(-)$ mean effective and ineffective, respectiviely. The number of plus sigñs $(+)$ represents the degree of inhibition

\begin{tabular}{|c|c|c|c|c|c|}
\hline Compound & $\begin{array}{c}\mathrm{MDA} \\
\text { formation }\end{array}$ & $\begin{array}{c}\left.{ }^{14} \mathrm{C}\right] \mathrm{Cl}_{4} \\
\text { binding } \\
\text { to lipids }\end{array}$ & $\begin{array}{c}\mathrm{CO} \\
\text { production }\end{array}$ & $\begin{array}{l}\text { NADPH } \\
\text { oxidation }\end{array}$ & $\begin{array}{c}\text { Oxygen } \\
\text { uptake }\end{array}$ \\
\hline $\operatorname{Sin} A$ & ++ & - & - & - & - \\
\hline $\operatorname{Sin} B$ & $++t$ & $+t+$ & $+t+$ & ++ & +++ \\
\hline $\operatorname{Sin} C$ & ++ & +++ & +++ & +++ & +++ \\
\hline Sol A & $+t$ & + & - & - & + \\
\hline Sol B & + & + & + & + & ++ \\
\hline Ser $A$ & + & ++ & ++ & $+t$ & + \\
\hline Ser B & + & ++ & ++ & ++ & $t$ \\
\hline DDB & + & ++ & + & +++ & ++ \\
\hline
\end{tabular}

on $\mathrm{CCl}_{4}$-induced lipid peroxidation and the binding of $\mathrm{CCl}_{4}$-metabolites to lipids of liver microsomes.
Moreover, Lu \& Liu (1989) recently reported that seven of the nine dibenzocyclooctene lignans at a final concentration of $1 \mathrm{mM}$ were 
TABLE VII

Effect of Sin B, Sol B and DDB on enzymes of liver smooth and rough endoplasmic reticula (SER, RER)

\begin{tabular}{|c|c|c|c|c|c|c|}
\hline & \multicolumn{2}{|c|}{$\begin{array}{l}\text { Cytochrome } \mathrm{P}-450 \\
\mathrm{nmol} / \mathrm{mg} \text { protein }\end{array}$} & \multicolumn{2}{|c|}{$\begin{array}{c}\text { NADPH-cytochrome } \mathrm{C} \\
\text { reductase } \\
\text { nmol/mg protein }\end{array}$} & \multicolumn{2}{|c|}{$\begin{array}{l}\text { Aminopyrine demethylase } \\
\mathrm{HCHO} \mathrm{nmol} / \mathrm{mg} \text { protein }\end{array}$} \\
\hline & SER & RER & SER & RER & SER & RER \\
\hline $2 \%$ Tween- 80 & $1.06 \pm 0.22$ & $1.25 \pm 0.30$ & $29.4 \pm 7.4$ & $21.1 \pm 4.4$ & $12.1 \pm 4.3$ & $8.2 \pm 6.5$ \\
\hline $\operatorname{Sin} B$ & $1.58 \pm 0.44^{a}$ & $1.40 \pm 0.50$ & $36.6 \pm 6.1$ & $23.4 \pm 2.5$ & $11.7 \pm 1.4$ & $15.9 \pm 5.8$ \\
\hline Sol B & $2.33 \pm 0.33^{b}$ & $1.25 \pm 0.31$ & $46.6 \pm 3.2^{b}$ & $24 \pm 3.7$ & $25.0 \pm 8.9^{b}$ & $14.4 \pm 3.3$ \\
\hline \multirow[t]{3}{*}{ DDB } & $2.58 \pm 0.53^{b}$ & $1.02 \pm 0.23$ & $42.7 \pm 4.3^{b}$ & $24.4 \pm 5.4$ & $24.6 \pm 3.0^{b}$ & $7.1 \pm 1.5$ \\
\hline & \multicolumn{3}{|c|}{ Protein $\mathrm{mg} / \mathrm{g}$ liver } & \multicolumn{3}{|c|}{$\begin{array}{c}\text { Glucose-6-phosphotase activity } \\
\text { OD } / \text { mg protein }\end{array}$} \\
\hline & \multicolumn{2}{|c|}{ SER } & RER & \multicolumn{2}{|c|}{ SER } & RER \\
\hline $2 \%$ Tween-80 & \multicolumn{2}{|c|}{$11.4 \pm 1.7$} & $10.7 \pm 0.4$ & \multicolumn{2}{|c|}{$0.75 \pm 0.08$} & \multirow{2}{*}{$0.85 \pm 0.03$} \\
\hline $\operatorname{Sin} B$ & \multirow{2}{*}{\multicolumn{2}{|c|}{$\begin{array}{c}9.9 \pm 4.2 \\
14.4 \pm 0.8^{b}\end{array}$}} & $13.7 \pm 3.2$ & \multicolumn{2}{|c|}{$0.82 \pm 0.10$} & \\
\hline Sol B & & & $9.4 \pm 0.6$ & \multirow{2}{*}{\multicolumn{2}{|c|}{$0.95 \pm 0.07 b$}} & $\begin{array}{l}0.86 \pm 0.08 \\
0.70 \pm 0.07\end{array}$ \\
\hline DDB & \multicolumn{2}{|c|}{$15.6 \pm 1.9^{b}$} & $10.6 \pm 1.4$ & & $0.79 \pm 0.07$ & $0.83 \pm 0.06$ \\
\hline
\end{tabular}

$a: \mathrm{p}<0.05 ; b: \mathrm{p}<0.01$ vs $2 \%$ Tween- 80 .

shown to inhibit $\mathrm{Fe}^{+++} /$cysteine induced lıpıd peroxidation (MDA formation) of rat liver microsomes as well as superoxide anion $\left(\mathrm{O}_{2}^{-}\right)$ production in xanthine/xanthine oxidase system to different degrees. The action of these lignans were much more potent than vitamin $\mathrm{E}$ at the same concentration. Among them, schisanhenol was the most active one. It is therefore suggested that these schisandrae neolignans are antioxidants.

EFFECTS ON ENZYMES OF LIVER SMOOTH AND ROUGH ENDOPLASMIC RETICULA (SER, RER)

Oral administration of Sin B, Sol B (150 mg/ $\mathrm{kg})$ or DDB $(200 \mathrm{mg} / \mathrm{kg})$ to mice once daily for 3 days induced a significant increase of cytochrome P.450 in SER but not in RER. Sol $B$ and DDB also increased NADPH-cytochrome $\mathrm{C}$ reductase and aminopyrine deme. thylase activities as well as protein concentration in SER. In addition, Sol B markedly enhanced the activity of glucose-6-phosphatase in SER, whereas Sin B was without these actions. The results indicated that $\operatorname{Sin} B$, Sol $B$ and DDB selectively induced different effects on drug metabolism enzymes in SER (Li \& Liu, 1987) (see Table VII).

\section{CONCLUSION}

From the Chinese traditional medicine Fructus Schizandrae, several neolignans were isolated and their chemical structures were identified. Animal studies revealed that some of them are effective in protecting liver injuries from chemical intoxicants and enhanced liver protein and glycogen synthesis. It was also found that some neolignans of Schizandraceae can induce liver microsomal P-450, thus inhibited xenobiotic metabolism and decreased the mutagenicity of some chemical mutagens.

Different preparations from Fructus Schizandrae have been used widely in China in recent years for the treatment of hepatitis, the total effective rate in lowering the elevated SGPT is over $84 \%$, among them $75 \%$ reached normal SGPT levels. It is not only effective in viral hepatitis but also for alcohol and drugs induced hepatic injuries. The synthetic derivate DDB has all the above activities and low toxicity, now producted in several Chinese pharmaceutical factories as the first choice drug in lowering elevated SGPT levels on patients suffering from chronic hepatitis. DDB winned a Brussels Eureka Prize of the World 
Fair Invention in 1987. From natural Schizandraceae lignans to the discovery of DDB pointed out a success way of developing new drugs from natural products.

\section{REFERENCES}

BAO, T. T.; XU, G. F.; LIU, G. T.; SUN, R. H. \& SONG, Z. Y., 1979. A comparison of the pharmacological action of seven constituents isolated from Fructus Schizandrae. Acto Pharm. Sin., 14: 1-7.

LI, Y. \& LIU, G. T., 1987. Schizandrins and DDB (diphenyl dimethyl bicarboxylate) on enzymes of liver smooth and rough endoplasmic reticula in rats. Acto Pharmacol. Sin., 8: 560-562.

LIU, G. T.; BAO, T. T.; WEI, H. L. \& SONG, Z. Y., 1980. Induction of hepatocyte microsomal cytochrome $\mathrm{P}-450$ by schizandrin B in mice. Acta Pharm. Sin., 15: 206-211.

LIU, K. T. \& LESCA, P., 1982a. Pharmacological properties of dibenzo $[\mathrm{a}, \mathrm{c}]$ cyclooctene derivatives isolated from Fructus Schizandrae chinensis I. Interaction with rat liver cytochrome P-450 and inhibition of xenobiotic metabolism and mutagenicity. Chem. Biol. Interact., 39: 301-314.

LIU, K. T. \& LESCA, P. 1982b. Pharmacological properties of dibenzo[a,c] cyclooctene derivatives isolated from Fructus Schizandrae chinensis. III. Inhibitory effects on carbon tetrachlorideinduced lipid peroxidation, metabolism and covalent binding of carbon tetrachloride to lipids. Chem. Biol. Interact., 41:39-47.

LIU, J. S., 1987. The chemistry and bioactivity of active principles of Schisandraceae plants. Organic Chem., 4:316-319.

LU, H. \& LIU, G. T., 1990. Anti-oxidant activity of nine dibenzocyclooctene lignans isolated from Fructus Schizandrae. Acta Pharmacol. Sin. to be published.

SHANGHAI INSTITUTE OF MATERIA MEDICA \& Third People's Hospital of Shanghai Second Medical College, 1976. Studies on the transaminase-lowering principles of Schisandra sphenanthera Rehd et Wils. Acta Biochem. Biophys. Sin., 8: 333-340. 